\title{
EPIDEMIOLOGICAL ASPECTS OF ASTROVIRUS AND CORONAVIRUS IN POULTS IN THE SOUTH EASTERN REGION OF BRAZIL
}

\author{
S.E.L. da Silva ${ }^{1}$; A.M. Bonetti ${ }^{1}$; A. Petrocelli ${ }^{1}$; H.F. Ferrari²; M.C.R. Luvizotto³ ${ }^{3}$ T.C. Cardoso ${ }^{2 *}$ \\ ${ }^{1}$ Universidade Federal de Uberlândia, Departamento de Genética e Biologia Molecular, Uberlândia, MG, Brasil; ${ }^{2}$ Universidade do \\ Estado de São Paulo, Departamento de Apoio, Produção e Saúde Animal, Faculdade de Odontologia, Curso de Medicina \\ Veterinária, Universidade Estadual Paulista, Araçatuba, SP, Brasil; ${ }^{3}$ Universidade Estadual Paulista, Departamento de Clínica, \\ Cirurgia e Reprodução Animal, Faculdade de Odontologia, Curso de Medicina Veterinária, Universidade Estadual Paulista, \\ Araçatuba, SP, Brasil.
}

Submitted: May 21, 2008; Returned to authors for corrections: July 10, 2008; Approved: March 31, 2009.

\begin{abstract}
A survey of Turkey Coronavirus (TCoV) and Astrovirus (TAstV-2) prevalence was carried out from February to December during 2006 year in semiarid region of Brazil, from a turkey producer area, localized in South Eastern of Brazil. To asses the risk factor related to clinical material, climatic condition and type of RT-PCR applied, cloacal swabs (CS), faeces, sera, bursa of Fabricius (BF), thymus (TH) and spleen (SP) and ileumcaeca region were collected from 30-day-old poults suffering of enteritis episode characterized as poult enteritis mortality syndrome (PEMS). The PEMS clinical features were characterized by watery to foamy faeces, light brown-yellow in colour and low mortality rate. Meteorological data (rainfall and relative humidity) observed during along the study presented monthly average temperature ranging from 39.3 and $31.2^{\circ} \mathrm{C}$, precipitation in rainy season from 40 to $270.3 \mathrm{~mm} / \mathrm{month}$, and no rain during dry season. Simplex RT-PCR gave odds ratio $(\mathrm{OR})$ values suggesting that ileum-caeca region is at higher chance $(\mathrm{OR}=1.9 ; p=0.9741)$ to have both viral RNA than faeces $(\mathrm{OR}=1.5 ; p=0.7319)$. However, multiplex RT-PCR showed $3.98(p=0.89982)$ more chance to give positive results in faeces than CS at dry season. The major risk factors seem to be low rate of humidity and high temperatures at winter, probably responsible for spread, easily, the TCoV and TAstv-2 among the flocks. The positive results of both virus suggested that they can play an important role in enteric disorders, associated to low humidity and high temperatures frequently found in tropical countries.
\end{abstract}

Key words: Turkey Astrovirus, Turkey Coronavirus, molecular diagnosis, PEMS

\section{INTRODUCTION}

Avian astroviruses belong to the genus Avastrovirus of the Astroviridae family. The viral particles are small, non-enveloped, positive sense RNA viruses, 28 to $30 \mathrm{~nm}$ in diameter, and have a star-like morphology (21). Turkey Astrovirus type 1 (TAstV-1) was first described in 1980 by McNulty et al. (22) in the United Kingdom, and the first isolated of TAstV in the United States was identified in 1985 (15). A second TAstV type, which was antigenically and genetically distinct from the previously identified as TAstV-1, was isolated 1996 and designated as
$\mathrm{TAstV}-2(13,31,32)$. The entire genome sequence of the TAstV2 isolate, $\mathrm{NC} / 96$, has been reported and bears many similar features to Human Astrovirus (HAstV) (15). Moreover, astroviruses are linked with enteric disease in humans and young animals such as calves, lambs, pigs, dogs, cats and minks $(15,21)$. The most important infectious disease caused by TAstV are the enteric diseases affecting the digestive tract of commercial poults proposed to result in more economic loss than those affecting any other system reported worldwide, including Brazil $(16,17,26,27,28,30,34,35)$. In addition, no vaccine currently exists for the enteric disease caused by astroviruses,

*Corresponding Author. Mailing address: UNESP, DAPSA, Rua Clóvis Pestana 793, curso Medicina Veterinária, FOA-UNESP, Araçatuba, SP. 16050-680, Brasil. Tel.: 18 3636-1568 Fax: 18 3636-1352. E-mail: tcardoso@fmva.unesp.br 
which leads the disease to the bio-security manners to control virus infection and spread (15).

Turkey Coronavirus (TCoV) was described affecting commercial poults in Brazil, suspected of suffer from PEMS Poult Enteric Mortality Syndrome (34,35). In addition, coronaviruses had often been described as being fastidious. This claim arose from the difficulty that virologists had experienced in finding types of cells in which grow coronaviruses in vitro $(7,11)$. Moreover, the $\mathrm{TCoV}$ was confirmed as being in the UK in 2001 (6) and has being demonstrated as worldwide distribution (7).

Alternatives to diagnosis both $\mathrm{TAstV}-2$ and $\mathrm{TCoV}$, and also others viruses, has been applied in order to overcome virus isolation (5). In this way, molecular approaches seems to be more appropriated to direct detect viral RNA from clinical samples, by the use conventional and/or alternative reverse transcriptase polymerase chain reaction - RT-PCR $(1,5,8,14,18,24,25,29)$. Since both viruses have been associated to PEMS outbreak in North America $(1,2,13,18,22,23,24,27,29)$ and recently UK and Wales (9), few works describe TCoV and TAstV-2 epidemiology among Brazilian's producers.

The aim of this study was to verify viral RNA from TCoV and TAstV-2 from 30-day-old affected poults, presenting clinical signs of PEMS. For this purpose, both simplex and multiplex RT-PCR assays were applied to detect viral RNA from different clinical samples at different year seasons.

\section{MATERIALAND METHODS}

\section{Micro-region and flocks}

In Brazil, the turkey industry is divided into two distinct regions: one localized in the South and other in the South-eastern, distant more than $10.000 \mathrm{Km}$ from each other, presenting annual production of 187 millions of carcases, condition that placed Brazil as the second producer in the world. Based on the climatic characteristic, these two regions are totally opposite from each other. The producer region chosen for the present study is characterized by high relative humidity during the summer and dried winter, mean monthly temperatures ranged $30^{\circ} \mathrm{C}$, localized in South Eastern of the country. The samples were collected in 5 times point, along the year from February to December, including summer and winter. The flocks aged $\cong 30$ days, distant from each other $2 \mathrm{Km}$, presenting more than 10.000 birds in a large growing scale under straight bio-security manners, presenting $10 \%$ of mortality in average were included on this study. The samples were collected monthly by specialized veterinarians, and sent to Laboratory under $-4^{\circ} \mathrm{C}$ for virology investigation. The general description of the common symptoms observed during the disease course was collected by a questionnaire filled at the time of each collection and characterized as being depression, huddling, dehydration, stunted growth and loss of appetite. No healthy turkeys were analysed here.

\section{Samples}

To verify the presence of viral TAstV-2 and TCoV a study was designed as follow: the birds were submitted to necropsy and slices of bursa of Fabricius (BF; $n=12$ ), thymus (TH; $n=10$ ), spleen (SP; $n=40)$, ileum-caeca region $(n=20)$ were collected. The non coincidence between number of collected organs and number of studied poults was due to time after death. So, by macroscopic evaluation only organs without necrosis were used for the study. Half of each organ was kept under $-86^{\circ} \mathrm{C}$ as a source of original virus, and the other half readily submitted to prepare the respective tissue suspension (34). The respective cloacal swabs $(C S ; n=500)$, faeces $(n=500)$ and sera $(n=500)$ were collected from symptomatic birds stored under $-86^{\circ} \mathrm{C}$ until its use. The criterion of inclusion used was: prevalence of at least $25 \%$ for both viruses, a confidence interval (CI) of $95 \%$ and a mean flock size of 5000 birds (range 1.000-10.000). In order to determine the major risk factor involved (climatic conditions) in disseminate both viruses amongst turkeys from the same flock, the CS and respective faeces were assayed, and the results compared according to percentage of positives (winter and summer) found by both RT-PCR approaches.

\section{Preparation of clinical samples for RT-PCRs}

The CS, sera, faeces and tissues suspensions prepared from $\mathrm{BF}, \mathrm{TH}, \mathrm{SP}$ and ileum-caeca region were prepared according to previous report (34). In our laboratory no Astrovirus is currently available, so it was not used TAstV-2 as positive control in this study to verify the specificity, however other RNA virus, IBV (Infectious bronchitis virus), was included as negative control for TAstV-2 and positive control for TCoV. In order to verify the Rotavirus and Reovirus presence, the samples were used to infect MA and Vero cells, at three times consecutively, which are not able to support TCoV neither TAstV-2 replication. However, to confirm the absence of these two viruses, pool of all positive samples were submitted to PAGE (polyacrilamide gel electrophoresis analysis) (25).

\section{Simplex and multiplex RT-PCR}

The total RNA was extracted by TRIzol ${ }^{\oplus}$ standard protocol with some modifications (34). The total RNA extracted was dissolved in $30 \mu \mathrm{l}$ of diethyl-pyrocarbonate (DEPC) treated sterile double-distilled water and stored at $-20^{\circ} \mathrm{C}$ until use. The TAstV-2 specific primers MKPOL10 (forward) and MKPOL11 (reverse) were used to amplified 785-bp fragment within the polymerase gene (30). An internal RT-PCR control, beta actin gene loci of Meleagris gallopavo genome was used to avoid no specific reactions as a house keeping gene. The beta-acitin gene was amplified by using the oligonucleotides: beta actin foward (5'-AAGATCTGGCACCACACTTTC- $3^{\prime}$ ) and beta actin reverse ( $5^{\prime}$ - ACAGCTTCTCCTTGATGTCAC- 3 ') reported in GenBank accession number X00182, able to produced a fragment of $400 \mathrm{pb}(30,33)$. For the Coronavirus (TCoV) detection, a set 
of primers used were a combination of UTR11-/UTR41+ which are incriminated to produce a very sensitive RT-PCR (6). Before the RT-PCRs had been performed all total RNA were heated during $3 \mathrm{~min}$ at $100^{\circ} \mathrm{C}$, followed by $2 \mathrm{~min}$ at $72^{\circ} \mathrm{C}$ and finally $2 \mathrm{~min}$ at $50^{\circ} \mathrm{C}(34)$. The simplex and multiplex RT-PCR applied in all samples was conducted according to Teixeira et al. (34) and Pantin-Jackwood et al. (24), respectively. A total of $10 \mu \mathrm{l}$ of PCR products were electrophoresed at $100 \mathrm{~V}$ for $1 \mathrm{~h}$ in $1.5 \%$ agarose gel in $1 \times$ Tris-borate EDTA (TBE) buffer and visualized by ethidium bromide staining and ultraviolet (UV) transluminator. Gel images were captured using Kodak DC290 digital camera and ADOBE 8.0 software.

\section{Sequencing}

All the RT-PCR products were sequenced directly using the BigDye Terminator v3.1 cycle sequencing kit (Applied Biosystems) using the same set of primers in order to confirm the identity of the amplified products. The sequences were deposited as TCoV/Brazil/2006 accession number FJ188401 and TAstV-2/Brazil/2006 FJ178641, respectively $(9,14)$.

\section{Statistical analysis}

Descriptive statistics were used to determine the frequency of positive poults for TAstV-2 and TCoV in all samples tested and the two RT-PCR assays applied. The results of all samples were also used to estimate the apparent positivity during summer and winter. The apparent prevalence was adjusted for specificity and sensitivity of each test to obtain the true prevalence (19). A primary screening test to identify climatic characteristic significantly related to TAstV- 2 and $\mathrm{TCoV}$ positive results was performed using $\chi 2$-test. To calculate the specificity and sensitivity of each RT-PCR, the accuracy of two conditionally independent tests in the absence of a gold standard was used (10). Variable analysis was performed using the odds ratios (OR) to quantify the association between climatic conditions (summer and winter) and positively results for TAstV-2 and TCoV from $\mathrm{CS}$ and faeces; from TAstV-2 and TCoV in tissues and sera; from TAstV-2 and TCoV RT-PCRs. The Microsoft Access for Windows and statistical comparisons were performed using the Microsoft Excel 8.0 and Epi-Info 3.3 version. Differences were considered significant when $p$ values were less than 0.05 .

\section{RESULTS}

\section{Climatic conditions}

South Eastern of Brazil is classified as being tropical wet and dry or savannah (Aw) type according to Köpper climate classification system, since the area presents an extend dry season during winter (end of May to September) temperature winter month $>20^{\circ} \mathrm{C}$ and rainy season during summer (October to March approximately) precipitation in the driest summer month $<30 \mathrm{~mm}$ (19). The meteorological data (rainfall and relative humidity) for this region during the period of study presented monthly average temperature ranging from 39.3 and $31.2^{\circ} \mathrm{C}$, the precipitation in rainy season varied from 40 to $270.3 \mathrm{~mm} / \mathrm{month}$, and there was no rain at all during dry season (results not shown).

\section{Prevalence of TAstV-2 and TCoV assayed by RT-PCRs}

TAstV-2 prevalence was 80 and $70 \%$ from analyzed sera using both RT-PCR approaches, respectively (Table 1 and 2). No evidence of viral RNA corresponding to $\mathrm{TCoV}$ was detected in the sera. However, amongst BF, TH and SP assayed for TAstV-2 100\%, 100\% and 50\% were positive, respectively. From the same analysis, no TCoV viral RNA was detected (Table 1 and 2). Ileum-caeca region demonstrated $100 \%$ of positive results. The highest likelihood of infection for both viruses was found amongst faeces collected, whereas $100 \%$ and $80 \%$ were positive for TAstV-2 and TCoV ( $p=0.9417)$, respectively. Faeces suspected of TAstV-2 and TCoV co-infection were 1.9-fold more likely to present viral RNA than other clinical material for simplex RT-PCR searching. Multiplex RT-PCR revealed $80 \%$ and $30 \%$ of positive faeces for TAstV-2 and TCoV, respectively (Table 2). When the two viral RNA were searched by the same RT-PCR, the odds ratio $(\mathrm{OR})$ values suggested ileum-caeca at higher chance $(\mathrm{OR}=1.9 ; p=0.9741)$ of having both RNA than faeces $(\mathrm{OR}=1.5 ; p=0.7319)$.

\section{Prevalence of TAstV-2 and TCoV detected from CS and faeces during winter and summer, assayed by both RT-PCRs}

In order to verify the incidence of re-infection during this study, including RT-PCRs, CS, faeces and winter/summer results

Table 1. Positive results of viral RNA (TAstV-2 and TCoV) searched by simplex RT-PCR to amplify the TAstV-2 polymerase gene and TCoV 3 'UTR region, respectively.

\begin{tabular}{|c|c|c|c|c|c|c|}
\hline \multirow[b]{3}{*}{ Samples } & \multicolumn{2}{|c|}{$\begin{array}{l}\text { simplex } \\
\text { RT-PCR }\end{array}$} & \multicolumn{2}{|c|}{$\begin{array}{l}\text { simplex } \\
\text { RT-PCR }\end{array}$} & \multirow[b]{3}{*}{$\underset{p \text {-values }}{\chi}$} & \multirow[b]{3}{*}{ OR } \\
\hline & \multicolumn{2}{|c|}{$\begin{array}{l}\text { TAstV-2 } \\
\text { MKPOL }\end{array}$} & \multicolumn{2}{|c|}{$\begin{array}{l}\text { TCoV } \\
\text { 3UTR }\end{array}$} & & \\
\hline & $\begin{array}{l}\text { Positive } \\
\text { /Total }\end{array}$ & $\%$ & $\begin{array}{l}\text { Positive } \\
\text { /Total }\end{array}$ & $\%$ & & \\
\hline CS & $450^{\mathrm{a}}$ & 90 & 200 & 40 & 0.7917 & 1.9 \\
\hline Faeces & 500 & 100 & 400 & 80 & 0.9417 & \\
\hline Sera & 350 & 70 & 0 & - & & \\
\hline $\mathrm{BF}$ & 12 & 100 & 0 & - & & \\
\hline $\mathrm{TH}$ & 10 & 100 & 0 & - & & \\
\hline SP & 20 & 50 & 0 & - & & \\
\hline Ileum-caeca & 100 & 100 & 100 & 100 & & \\
\hline
\end{tabular}

a- Based on positive samples in comparison to the total samples analysed described in Material and Methods section. 
were compared (Table 3). For TAstV-2 search, $10 \%$ of CS and $20 \%$ of faeces were positive at winter, and $36 \%$ of CS and $20 \%$ of faeces showed an increase in the same period for TCoV, when individual RT-PCR was evaluated. In addition, the TAstV2 was less detectable, CS $50 \%$ and faeces $72 \%$, in the winter when multiplex RT-PCR was used (Table 3). Otherwise, the TCoV was equal detected from CS and $28 \%$ more detectable in winter for the same analysis. The results showed on Table 3, RT-PCR assayed for both virus in a single tube have $3.98(p=0.89982)$ more chance to present positive results (faeces) than CS, at dry

Table 2. Positive results of viral RNA (TAstV-2 and TCoV) searched by multiplex RT-PCR to amplify the TAstV-2 polymerase gene and TCoV 3 'UTR region.

\begin{tabular}{|c|c|c|c|c|c|c|}
\hline \multicolumn{7}{|c|}{ Multiplex RT-PCR } \\
\hline & \multicolumn{2}{|c|}{ TAstV-2 } & \multicolumn{2}{|c|}{$\mathrm{TCoV}$} & \multirow{2}{*}{$\begin{array}{c}\chi \\
p \text {-values }\end{array}$} & \multirow[t]{2}{*}{ OR } \\
\hline Samples & \multicolumn{2}{|c|}{ MKPOL } & \multicolumn{2}{|c|}{ 3UTR } & & \\
\hline CS & $350^{\mathrm{a}}$ & 70 & 200 & 40 & 0.7943 & 1.5 \\
\hline Faeces & 400 & 80 & 150 & 30 & 0.7319 & \\
\hline Sera & 420 & 84 & 0 & - & & \\
\hline $\mathrm{BF}$ & 12 & 100 & 0 & - & & \\
\hline $\mathrm{TH}$ & 10 & 100 & 0 & - & & \\
\hline SP & 35 & 87,5 & 0 & - & & \\
\hline Ileum-caeca & 90 & 90 & 100 & 100 & & 1.9 \\
\hline
\end{tabular}

a- Based on positive samples in comparison to the total samples analysed described on material and methods section. season, and faeces have 0.67 of chance to give false negative results for the same statistical analysis $(p=0.67851)$.

\section{Sequencing data}

Sequencing of the amplified products revealed a high homology with TAstV-2 North Carolina Q/34/1990 strain for

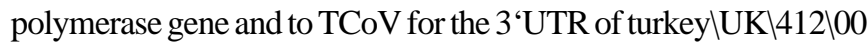
strain (FJ178641 and, respectively).

\section{DISCUSSION}

In previous studies in Europe and USA, and recently in South of America, TCoV and TAstV-2 were widely found affecting turkeys flocks, associated with a variety of clinical conditions and tissue damage $(6,8,9,13,16,30,34,35)$. The present study, clinical signs were described as marked accumulation of liquid in the small intestine, liquid and/or frothy cecal contents, and wet rectal contents, similar to those described before $(27,28)$. Likewise, affected flocks ceased growth and often lost weight for an extended of period, as reported by Culver et al. (8). The specimens analysed here were from turkeys aged 1 month or less, in spite of many reports have been showed the prevalence of TCoV upon 30 days and TAstV-2 in the two first weeks of life (13).

The simplex RT-PCR was able to increase the detection of both viral RNA in faeces, than other clinical material. The same analysis has been reported in England and Wales, when 52\% and $70 \%$ for $\mathrm{TCoV}$ and $\mathrm{TAstV}-2$ was evidenced from turkeys using the simplex RT-PCR assay $(1,9)$. Otherwise, the ileumcaeca junction was able to increase the chance of detect viral

Table 3. Year average rainfall $\left(\mathrm{mm}^{3}\right)$ and relative humidity $(\mathrm{RH} \%)$ in the turkey producer region: detection of viral RNA(TAstV-2 and TCoV) from CS and faeces searched by simplex and multiplex RT-PCR assays.

\begin{tabular}{|c|c|c|c|c|c|c|c|c|c|c|}
\hline & \multicolumn{4}{|c|}{ Simplex RT-PCR ${ }^{a}$} & \multicolumn{4}{|c|}{ Multipex RT-PCR ${ }^{b}$} & \multirow[b]{3}{*}{$\chi^{2} p$-values } & \multirow[b]{3}{*}{$\mathrm{OR}$} \\
\hline & \multicolumn{2}{|c|}{ TAstV-2 } & \multicolumn{2}{|c|}{$\mathrm{TCoV}$} & \multicolumn{2}{|c|}{ TAstV-2 } & \multicolumn{2}{|c|}{$\mathrm{TCoV}$} & & \\
\hline & Summer $^{\mathrm{c}}$ & Winter & Summer & Winter & Summer & Winter & Summer & Winter & & \\
\hline CS Positive & $200^{\mathrm{d}}$ & 250 & 10 & 190 & 300 & 50 & 100 & 100 & 0.87654 & 0.67 \\
\hline$\%$ & 40 & 50 & 2 & 38 & 60 & 10 & 20 & 20 & & \\
\hline CS Negative & $25^{\mathrm{e}}$ & 25 & 100 & 200 & 100 & 50 & 80 & 220 & 0.67851 & \\
\hline$\%$ & 5 & 5 & 20 & 40 & 20 & 10 & 16 & 44 & & \\
\hline Faeces Positive & 300 & 200 & 150 & 250 & 380 & 20 & 100 & 50 & 0.89982 & 3.98 \\
\hline$\%$ & 60 & 40 & 30 & 50 & 76 & 4 & 20 & 10 & & \\
\hline Faeces Negative & 0 & 0 & 20 & 80 & 50 & 50 & 300 & 50 & 0.56743 & \\
\hline$\%$ & _ & _ & 4 & 16 & 10 & 10 & 60 & 10 & & \\
\hline
\end{tabular}

a- simplex RT-PCR performed as described in material and methods section;

b- Multiplex RT-PCR performed as described in material and methods section;

c- Year average rainfall and humidity year $2006250 \mathrm{~mm}^{3}$ and $78 \%$ (summer); $0 \mathrm{~mm}^{3}$ and $40 \%$ (winter);

d- Positive results related to total samples analyzed described in material and methods section;

e- Negative results related to total samples analyzed described in material and methods section. 
RNA, when compared to faeces for the same analysis by the use of a multiplex RT-PCR performed in a single tube reaction $(18,29)$ In addition, the multiplex RT-PCR is widely used for epidemiological studies in USA, showing efficiency and specificity when an internal control template (29). Moreover, this is the first study reporting the applicability of multiplex RTPCR performed on different clinical material. Interesting, the TAstV-2 could be detected, for the first time in sera collected from naturally infected poults, demonstrating early stages of virus infection characterized by viremic phase, only reported in experimentally infection $(17,26)$.

Herein, major risk factor was described as being faeces samples, whereas both virus RNA were 3.98 times more evidenced in winter by the use of multiplex RT-PCR assay. In spite of bio-security measures implemented elsewhere, the TCoV and TAstV-2 control in endemic areas has proven to be difficult (25). In a recent study, periodic monitoring of commercial turkey for enteric viruses has indicated continuous presence of astrovirus among healthy flocks (25). Otherwise, recent $\mathrm{TCoV}$ outbreak in North Carolina, a potential vector has been indicated responsible for spread the virus, since the incidence of infection increase during summer months, coinciding with increased fly populations (3). Besides, the outbreak observed in Wales and England in summer 2004 was probably occasioned by multi-age farms management, when the simple rescheduling of production resulted in a substantial reduction in number of affected birds (9). As shown by the results, in tropical countries the incidence of the same disease was observed during winter season, as reported by Teixeira et al. $(28,30)$ and Villareal et al. (35). Concern about sequencing, recent work has demonstrated that genetic differences on TAstV-2 capsid gene do not promote any different enteric disease (26). In this way, the infection of TAstV2 may affect the immune system by causing bursal lymphoid depletion, which can explain the positive results obtained from this tissue. Recently, it has demonstrated young poults affected by Poult Enteritis Complex (PEC) showing impairment of lymphoid organs $(28,30)$. Furthermore, TAstV-2 and TCoV has been described to co-circulate among different species $(4,12)$. However, more studies are still necessary to explain this mechanism associated to others enteric pathogens among Brazilian flocks (35).

Other major risk factor, climatic conditions, revealed here was the low rate of humidity and high temperatures winter, which increased the air-suspended particles, as faeces, and may be allows easily spread TCoV and TAstv-2 by the wind. As a consequence, effective control of endemic areas, in tropical countries, is dependent upon managing the litter, proper faeces disposable and climatic factors of the semiarid areas, which consequently affect the PEMS prevention. It is important to emphasize that, in spite of high bio-security level of turkey production worldwide the enteric episodes are still the major concern among avian pathologists.

\section{ACKNOWLEDGMENTS}

This work was supported by FAPESP - Fundação Amparo à Pesquisa do Estado de São Paulo-FAPESP (Grant number 05/ 51484-1; 07/55932-4). We are indebt to the technical team from SADIA-Unidade Uberlândia, MG, Brazil.

\section{RESUMO}

\section{Aspectos epidemiológicos associados à prevalência de Astrovirus e Coronavirus em lotes de perus da Região Sudeste do Brasil}

O presente estudo foi conduzido para avaliar a prevalência do Coronavirus dos perus (TCoV) e Astrovirus tipo 2 (TAstV2) entre os meses de Fevereiro a Dezembro de 2006, em uma região produtora localizada no semi-árido a Sudeste do Brasil. Os principais fatores de risco associado a prevalência foram material clínico analisado, condições climáticas e tipo de técnica molecular empregada. Os sinais clínicos foram caracterizados como intenso fluido intestinal e baixo crescimento em aves jovens, sendo o material coletado swabs cloacais, fezes, soros, bursa de Fabrícius, segmentos do intestino delgado, timo e baço. Os dados meteorológicos (índice pluviométrico e umidade relativa) desta região, durante o período de estudo, foram de temperatura média mensal variando de 39.3 a $31.2^{\circ} \mathrm{C}$, precipitação na época chuvosa variando de 40 a $270.3 \mathrm{~mm} / \mathrm{mês}$ e ausência de chuva na estação fria e seca. A técnica de simplex RT-PCR resultou em valores de odds ratio (OR) que sugerem que a região do intestino delgado (junção íleo-cecal) possui alta chance (1.9 vezes) de gerar resultados positivos na amplificação de RNA viral que as fezes (1.5 vezes) analisadas. A técnica de multiplex RT-PCR demonstrou ser 3.98 vezes mais eficiente em promover resultados positivos nas fezes que nos swabs cloacais, durante a época de inverno. Os maiores fatores de risco encontrados foram baixa umidade relativa associada a altas temperaturas, durante a estação seca, o que pode permitir uma maior disseminação aérea do ambos os vírus entre os lotes estudados. A alta prevalência detectada para dois vírus sugerem que, no Brasil, estes representam os maiores responsáveis pelos surtos de enterite viral nas regiões semiáridas, associado a baixas umidades e altas temperaturas típicas de países tropicais.

Palavras-chaves: Astrovirus perus, Coronavirus perus, diagnostico molecular, prevalência

\section{REFERENCES}

1. Breslin, J.J.; Smith, L.G.; Barnes, H.J.; Guy, J.S. (2000). Comparison of virus isolation immunohistochemistry and Reverse TranscriptasePolymerase Chain Reaction procedures for detection of Turkey Coronavirus. Avian Dis., 44: 624-631. 
2. Brown, T.P.; Garcia, A.P.; Kelly, L. (1997). Spiking mortality of turkey poults: I. Experimental reproduction in isolation facilities. Avian Dis., 41: 604-609.

3. Calibeo-Hayes, D.; Denning, S.S.; Stringham, S.M.; Guy, J.; Smith, L.G.; Watson, D.W. (2003). Mechanical transmission of turkey coronavirus by domestics houseflies (Musca domestica Linnaeaus). Avian Dis., 47: 149-153.

4. Cattoli, G.; Battisti, C. De.; Toffan, A.; Salviato, A.; Lavazza, A.; Ceriolli, M.; Capua, I. (2006). Co-circulation of distinct lineages of astroviruses in turkey and guinea fowl. Arch. Virol., 152: 595-602.

5. Cavanagh, D.; Mawditt, K.; Shaw, K.; Britton, P.; Naylor, C. (1997). Towards the routine application of nucleic acid technology for avian disease diagnosis. Acta Vet. Hung., 45: 281-298.

6. Cavanagh, D.; Mawditt, K.; Sharma, M.; Drury, S.E.; Ainsworth, H.L.; Britton, P.; Gough, R.E. (2001). Detection of a coronavirus from turkey poults in Europe genetically related to infectious bronchitis virus of chickens. Avian Path., 30: 365-378

7. Cavanagh, D. (2005). Coronaviruses in poultry and other birds. Avian Path., 34: 439-448.

8. Cardoso, T.C.; Castanheira, T.L.L.; Teixeira, M.C.; Rosa, A.C.; Hirata, K.Y.; Astolphi, R.D.; Luvizotto, M.C.R. (2008). Validation of an immunohistochemistry assay to detect turkey coronavirus: a rapid and simple screening tool for limited resource settings. Poult. Sci., 87: 1347-1352.

9. Culver, F.; Dziva, F.; Cavanagh, D.; Stevens, M.P. (2006). Poults enteritis and mortality syndrome in turkeys in Great Britain. Vet. Rec., 159: 209-210.

10. Georgiadis, M.P.; Johnson, W.O.; Gardner, I.A. (2005). Sample size determination for estimation of the accuracy of two conditionally independent tests in the absence of a gold standard. Prev. Vet. Med., 71: $1-10$.

11. Gough, R.E.; Alexander, D.J.; Lister, M.S.; Cox, W.J. (1988). Routine virus isolation or detection in the diagnosis of diseases of birds. Avian Pathol., 17: 893-907.

12. Gough, R.E.; Drury, S.E.; Francesca, C.; Britton, P.; Cavanagh, D. (2006). Isolation of a coronavirus from a green-cheecked Amazon parrot (Amazon viridigenalis Cassin). Avian Pathol., 35: 122126.

13. Guy, J.S.; Miles, A.M.; Smith, L.; Fuller, F.J.; Schultz-Cherry, S. (2004) Antigenic and genomic characterization of Turkey enterovirus-like virus (North Carolina, 1988 Isolate): Identification of the virus as Turkey Astrovirus 2. Avian Dis., 48: 206-211.

14. Koci, M.D.; Seal, B.S.; Schultz-Cherry, S. (2000). Development of an RT-PCR diagnostic test for an avian astrovirus. J. Virol. Meth., 90: $79-83$

15. Koci, M.D.; Schultz-Cherry, S. (2002). Avian Astroviruses. Avian Path., 31: 213-227.

16. Koci, M.D.; Moser, L.A.; Kelley, L.A.; Larsen, D.; Brown, C.C.; Schultz-Cherry, S. (2003). Astrovirus induces diarrhea in the absence of inflammation and cell death. J. Virol., 77: 11798-11808.

17. Koci, M.D.; Kelley, L.A.; Larsen, D.; Schultz-Cherry, S. (2004). Astrovirus-induced synthesis of nitric oxide contributes to virus control during infection. J. Virol., 78: 1564-1574.

18. Loa, C.C.; Lin, T.L.; Wu, C.C.; Bryan, T.A.; Hooper, T.; Schrader, D. (2006). Differential detection of turkey coronavirus, infectious bronchitis virus, and bovine coronavirus by a multiplex polymerase chain reaction. J. Virol. Meth., 131: 86-91.
19. Maia, M.G.; Costa, R.T.; Haddad, J.P.A.; Passos, L.M.F.; Ribeiro, M.F.B. (2007). Epidemiological aspects of canine babesiosis in the semiarid area of the state of Minas Gerais, Brazil. Prev. Vet. Med. 79: $155-162$.

20. Martin, S.W.; Meek, A.H.; Willeberg, P. (1987). Veterinary Epidemiology. Ames: Iowa State University Press.

21. Matsui, S.M.; Greenberg, H.B. (2001). Astroviruses. In: D.M. Knipe \& P.M. Howley (Eds.). Fields Virology $4^{\text {th }}$ edn v 1, p. 875-893; Baltimore, MD: Lippincott Williams and Wilkins.

22. McNulty, M.S.; Curran, W.L.; McFerran, J.B. (1980). Detection of astroviruses in turkey faeces by direct electron microscopy. Vet. Rec., 106: 561.

23. Patin-Jackwood, M.J.; Spackman, E.; Woolcock, P.R. (2006) Phylogenetic analysis of turkey astroviruses reveals evidence of recombination. Virus Genes, 32: 187-192.

24. Patin-Jackwood, M.J.; Spackman, E.; Woolcock, P.R. (2006). Molecular characterization and typing of chicken and turkey Astroviruses circulating in the United States: Implications for Diagnostics. Avian Dis., 50: 397-404.

25. Patin-Jackwood, M.J.; Spackmann, E.; Day, J.M.; Rives, D. (2007) Periodic monitoring of commercial turkey for enteric viruses indicates continuous presence of astrovirus and rotavirus on the farms. Avian Dis., 51: 674-680.

26. Pantin-Jackwood, M.J.; Spackmann, E.; Day, M. (2008). Pathogenesis of type 2 turkey astroviruses with variant capsid genes in 2-day-old specific pathogen free poults. Avian Pathol., 37: 193-201.

27. Saif, Y.M.; Saif, L.J.; Hofarce, C.L.; Hayhow, C.; Swayne, D.E.; Dearth, R.N. (1990). A small round virus associated with enteritis in turkey poults. Avian Dis., 34: 762-764

28. Schultz-Cherry, S.; Kapczynski, D.R.; Simmons, U.N.; Koci, M.D.; Brwon, C.; Barnes, H.J. (2000). Identifying agent(s) associated with poult enterititis mortality syndrome: importance of the thymus. Avian Dis., 44: 256-265.

29. Sellers, S.H.; Koci, M.D.; Linnemaun, E.; Kelley, L.; Schultz-Cherry, S. (2004). Development of a multiplex reverse transcriptionpolymerase chain reaction diagnostic test specific for Turkey Astrovirus and Coronavirus. Avian Dis., 48: 531-539.

30. Silva, S.E.L.; Bonetti, A.M.; Petrocelli, A.T.M.; Ferrari, H.F.; Luvizotto, M.C.R.; Cardoso, T.C. (2008). Detection of turkey astrovirus in young poults affected with poult enteritis complex in Brazil. J. Vet. Med. Sci., 70: 629-631.

31. Tang, Y.; Saif, M. (2004). Antigenicity of two Turkey Astrovirus isolates. Avian Dis., 48: 896-901.

32. Tang, Y.; Murgia, M.V.; Saif, Y.M. (2005). Molecular characterization of the capsid gene of two serotypes of Turkey Astroviruses. Avian Dis., 49: 514-519.

33. Tang, Y.; Wang, Q.; Saif, Y.M. (2005). Development of a ssRNA internal control template reagent for a multiplex RT-PCR to detect turkey astroviruses. J. Virol. Meth., 126: 81-86.

34. Teixeira, M.C.B; Luvizotto, M.C.R.; Ferrari, H.F.; Mendes, A. R.; Cardoso, T.C. (2007). Detection of Turkey Coronavirus in commercial turkey poults in Brazil. Avian Path., 36: 29-33.

35. Villareal, L.Y.B.; Assayag, M.S.; Brandão, P.E.; Chacón, J.L.V.;Bunger, A.N.D.; Astolfi-Ferreira, C.S.; Gomes, C.R.; Jones, R.C.; Ferreira, J.A.P. Identification of Turkey Astrovirus and Turkey Coronavirus in an outbreak of poult enteritis and mortality syndrome. Rev. Bras. Cienc. Avic., 8: 131-135. 